\title{
The application of a stockpile stochastic model into long-term open pit mine production scheduling to improve the feed grade for the processing plant
}

Rudarsko-geološko-naftni zbornik

(The Mining-Geology-Petroleum Engineering Bulletin) UDC: 622

DOI: 10.17794/rgn.2020.4.10

Original scientific paper

\author{
Javad Gholamnejad'; Ali Azimi'; Reza Lotfian', Sara Kasmaeeyazdi², Francesco Tinti ${ }^{2}$ \\ ${ }^{1}$ Department of Mining and Metallurgical Engineering, Yazd University, University Blvd, Safayieh, Yazd, Iran \\ ${ }^{2}$ Department of Civil, Chemical, Environmental and Material Engineering, University of Bologna, via Terracini 28, Bologna, Italy
}

\begin{abstract}
This paper presents a chance-constrained integer programming approach based on the linear method to solve the longterm open pit mine production scheduling problem. Specifically, a single stockpile has been addressed for storing excess low-grade material based on the availability of processing capacity and for possible future processing. The proposed scheduling model maximizes the project NPV while respecting a series of physical and economic constraints. Differently from common practice, where deterministic models are used to calculate the average grade for material in the stockpiles, in this work a stochastic approach was performed, starting from the time of planning before the stockpile realization. By performing a probability analysis on two case studies (on iron and gold deposits), it was proven that the stockpile attributes can be treated as normally distributed random variables. Afterwards, the stochastic programming model was formulated in an open pit gold mine in order to determine the optimum amount of ore dispatched from different bench levels in the open pit and at the same time a low-grade stockpile to the mill. The chance-constrained programming was finally applied to obtain the equivalent deterministic solution of the primary model. The obtained results have shown a better feed grade for the processing plant with a higher NPV and probability of grade blending constraint satisfaction, with respect to using the traditional stockpile deterministic model..
\end{abstract}

\section{Keywords:}

open pit long-term production scheduling (OPLTPS), Stockpile management, linear programming (LP), mine planning, stochastic model

\section{Introduction}

The Open Pit Long-Term Production Scheduling (OPLTPS) procedure is a large scale optimization problem that aims to find the sequence of block extraction from the pit during the mine life, by reaching the maximum possible Net Present Value (NPV) whilst satisfying a variety of physical and economical constraints. The economic feasibility and also the optimality of mediumand short-term production scheduling of a mine is highly dependent on careful OPLTPS. Mathematical programming has been exploited to solve OPLTPS problems since the 1960s. A complete review on the applications of operation research and mathematical programming on the mine scheduling problem can be found in Osanloo et al. (2008) and Newman et al. (2010). Most of the models only considered mining and processing without taking into account the intermediate stage of stockpiling between mining and processing, usually used for the storage of low grade or excessive mined materials for possible future processing. In reality, materials of different grades are partially mixed within the stockpile and

Corresponding author: Francesco Tinti

francesco.tinti@unibo.it the final grade of material leaving the pile becomes a complex function of the material inside it (Kasmaee et al., 2018).

To date, stockpiles have been included in some shortand medium-term production scheduling models, with several professionals working on it. Among all, the present research lays its foundations on the following studies:

Smith (1999) considered the stockpile option in the grade blending constraints, while developing a combined mixed integer goal and separable programming techniques for short-term production scheduling of a phosphate open pit mine. The average grade of stockpile (in terms of $\mathrm{P}_{2} \mathrm{O}_{5}$ ) in each period was treated as a variable. Then, the separable term representing the product of the average grade of $\mathrm{P}_{2} \mathrm{O}_{5}$ in the stockpile and the quantity of ore reclaimed from the stockpile in a given time period was approximated by a piecewise linear function. After block aggregation and variable elimination, the model was solved using CPLEX's branch and bound algorithm.

Asad (2010) proposed a Linear Programming (LP) model for the short-term production scheduling of cement quarries and stockpile operations with the objective of cost minimization. Each quarry has a number of 
working benches at each scheduling period, and each bench has a stockpile holding the excess raw materials mined during a given period. The model updates each stockpile inventory on a weekly basis. The percentage of chemical content of each stockpile $(\mathrm{CaO}, \mathrm{SiO} 2, \mathrm{Al} 2 \mathrm{O} 3$, etc.) was supposed to be fixed and known.

Yarmuch and Ortiz (2011) proposed a linear model for optimizing the material flow between the open pit, one high grade and one low grade stockpile and an ore crusher, thus solving the short-term production scheduling problem for a copper mine. The proposed model was then solved period by period and the stockpile's grades were calculated at the end of each period.

Eivazy and Askari-Nasab (2012) formulated a multi-destination MIP model for the short-term production scheduling of an open pit mine which minimizes the total cost of mining operations, taking into account stockpiles for excess raw materials according to the rock type and grade range of ore, different routes for material haulage to final destinations and horizontal directional extraction of blocks along with the operational constraints. They assumed that stockpiles are homogenous, and the ore sent from each of them has a certain grade, equivalent to the average. To make this assumption closer to reality, they added two constraints to the model: the average grade of ore sent from the open pit to stockpiles in each time period must be in an acceptable range corresponding to each stockpile; after reclaiming ore from a stockpile, the average grade of remaining materials within it must remain in its acceptable grade range.

In the mentioned models, it is assumed that the materials in the stockpile are completely mixed, so that the grade of output ore is equal to the average of material within the stockpile. However, that is not always the case, especially in long-term stockpiles. Homogenization does not occur completely in these types of stockpiles and materials are dumped without any special order. As a matter of fact, an estimation of the properties of the reclaimed material from the stockpiles is difficult.

In the present study, it is assumed that during the mine lifetime, the extracted materials are firstly randomly stacked into the stockpile using dump trucks depending on their grades, and secondly randomly reclaimed in "buckets" with the tonnage of each equal to the amount of material shortage at that scheduling period. So, the average grade of the material reclaimed from the stockpile is a random variable whose grade distribution function is equal to the distribution function of the materials sent to that pile. The research novelty consists of inserting this distribution function into the mathematical model of the OPLTPS problem, which is related to previous works over the use of chance-constrained programming approaches in stochastic environments (Gholamnejad and Karimi, 2006; Gholamnejad and Osanloo, 2007; Gholamnejad et al., 2008). The approach has been tested and validated on a case study of single stockpile of an open pit gold mine with infinite capacity.

In the following sections, after a short presentation of stockpile role in production scheduling of mines, the model showing the probabilistic behaviour of a single stockpile is proposed. Afterwards, the deterministic form of the OPLTPS model considering the stockpile option is stated. Next, the chance-constrained programming approach is applied for incorporating the probabilistic behaviour of stockpile grade. Finally, the numerical results for the medium-large size gold deposit case study are provided and discussed.

\section{Materials and methods}

This section is divided in two parts:

- The first part is devoted to the presentation of the stochastic nature of the stockpiles, demonstrated over two case studies: on one gold and one iron mine;

- The second part introduces the entire OPLTPS model, including the contribution of the stochastic stockpile to the whole process.

\subsection{Stockpiles in production scheduling of mines}

\subsubsection{Role of stockpile in mining process}

Stockpiling is an intermediate stage between mining and processing in most open pit and underground mines. Some valuable material may be stored in stockpiles; for example, a low-grade stockpile takes material that is only marginally unprofitable for a mill feed and stores it

Table 1: Four roles of stockpiles in mining operations (Jupp et al., 2013)

\begin{tabular}{|l|l|}
\hline Purpose & Description and Example \\
\hline Storing & $\begin{array}{l}\text { Stockpiles can store ore material that does not meet current blend characteristics. On the other } \\
\text { hand, these "wastes" can become economic in the future. These stockpiles are usually referred } \\
\text { to as long-term stockpiles. }\end{array}$ \\
\hline Buffering & $\begin{array}{l}\text { Stockpiles can be used as a buffer for solving short-term fluctuations in production or plant } \\
\text { processes. }\end{array}$ \\
\hline $\begin{array}{l}\text { Blending for } \\
\text { characteristic separation }\end{array}$ & Stockpiles can provide choices of specific blends into the crusher depending on requirements. \\
\hline $\begin{array}{l}\text { Blending for } \\
\text { homogenization }\end{array}$ & $\begin{array}{l}\text { Stockpiles can be used to improve homogenization of the ore material, for its efficient inclusion } \\
\text { in the plant feed }\end{array}$ \\
\hline
\end{tabular}


for possible future processing, when technology or market prices change (Morley and Arvidson, 2017). Jupp, Howard and Everett (2013) described the main purposes of ore stockpiling, which is summarized in Table 1.

It should be noted that it is possible to combine more than one approach into a single stockpile.

\subsubsection{Investigation on the stochastic behaviour of stockpile grade}

Due to the lack of stockpile spatial models, the prediction of ore feed quality from stockpiles to the processing plant is difficult. The reason lies in the fact that, before solving the model, it is not clear which blocks are going to be sent to the stockpile and how much ore is removed from the stockpile to the mill during a given period.

In geostatistics, the term support refers to the size and volume of a block, for estimation. In the stockpiles, each block contains the quantity of material that can be excavated and removed. According to the selected range of ore concentration in the mine, a distribution of grades (in blocks of $1 \times 1$ cell) can be assigned to the stockpile. By increasing the block size, more stockpile blocks are merged, and the distribution of the original data is no longer represented. When comparing the different sizes of the blocks from a stockpile, the means of ore concentration are the same, while the variances decrease with the growing volume. Theoretically, if the entire stockpile was excavated with only one bucket, its variance would have been zero. When dealing with a stockpile, understanding the behaviour of grade variance by varying the block size can be useful to better control the ore concentration before the raw material enters the processing plant. The optimum support of the blocks should be calculated by knowing their exact position in the stockpile. When this information is not available (a common case for stockpiles), it is however possible to have a preliminary indication of the values' dispersion by calculating the variance for all data, with different block sizes.

In order to clarify this issue, the behaviour of two stockpiles, one in a gold mine and another in an iron mine, has been simulated using the Monte Carlo Simulation method. There are three assumptions for these simulations:

- Assumption 1: Each stockpile has grade threshold limits (lower and upper) for selecting the blocks to be included there;

- Assumption 2: The grade of material in each stockpile is a random variable with a distribution function equal to the distribution function of the blocks inside the pit outline, whose grades are between the two above mentioned lower and upper thresholds;

- Assumption 3: There is no spatial correlation between the materials in the stockpile.

\section{Case study 1: An open pit gold mine}

The first mine is a conventional open pit mine. The final pit contains 855,400 tons of ore with an average grade of $1.57 \mathrm{~g} / \mathrm{t}$ Au at $0.60 \mathrm{~g} / \mathrm{t}$ cut-off grade. There are 1,807 blocks within the final pit limit of the deposit with the dimension of $6 \mathrm{~m} \times 6 \mathrm{~m} \times 5 \mathrm{~m}$. It is assumed that excess mineralized materials with a grade of less than $0.6 \%$ will be sent to a low-grade stockpile. The grade distribution function of $\mathrm{Au}$ for $\mathrm{Au}<0.60 \mathrm{~g} / \mathrm{t}$ can be seen in Figure 1.

Based on assumption 2, the frequency behaviour shown in Figure 1 governs the grade of gold blocks within the stockpile, too. The constructed stockpile in this mine contains 3,476 blocks with the dimensions of $3 \mathrm{~m} \times 3 \mathrm{~m} \times 3 \mathrm{~m}$ in three benches with a $3 \mathrm{~m}$ height. Then, 15 equiprobable images of stockpile are generated using the Monte Carlo Simulation (MCS) method. Monte Carlo simulation consists of creating alternative samples (realizations) from the input parameters, evaluating the model response for each of these realizations, and constructing the corresponding distribution of model predictions (Goovaerts, 1997). In each simulation, a set of 3,476 gold grade were generated using MCS and used as input to the stockpile block model. The histogram of $\mathrm{Au}$ for the first simulation can be seen in Figure 2. Also, the

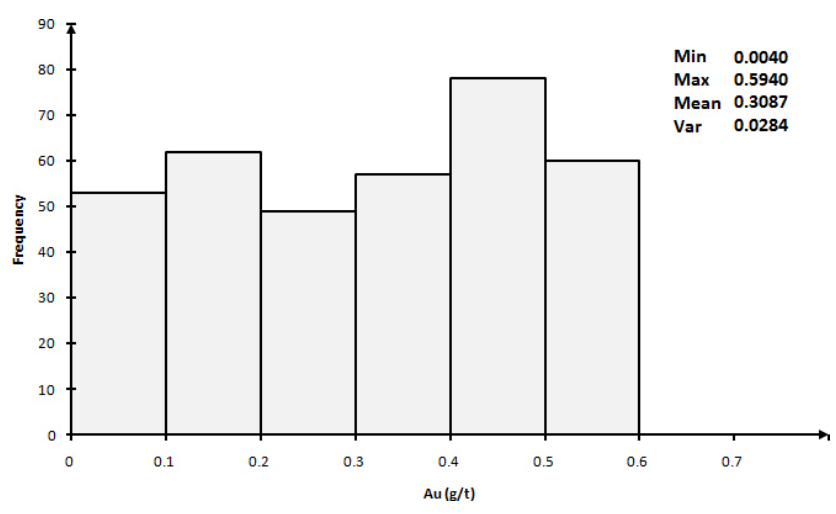

Figure 1: Histogram of gold grade blocks for $\mathrm{Au}<0.60(\mathrm{~g} / \mathrm{t})$ in the orebody

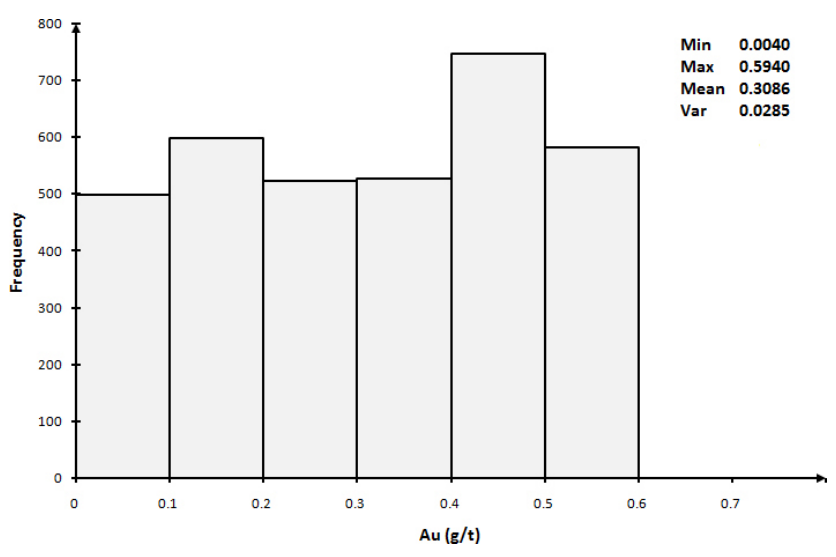

Figure 2: Histogram of gold grade blocks in the stockpile for the first simulation (of 15 ) 
statistical characteristics of the Au grade in fifteen simulations are summarized in Table 2.

The tonnage of ore sent from the mine to the stockpile and from the stockpile to the mill is not yet determined. In order to estimate the grade distribution function of feed from stockpile to mill, the block sizes are increased by merging adjoining blocks, averaging their values and then calculating the statistical parameters of the resulting block models. In this way, the excavated tonnage from the stockpile is supposed to be equal to the tonnage of the merged blocks.

The sizes of the seven block models are determined as:

1. $3 \mathrm{~m} \times 3 \mathrm{~m} \times 3 \mathrm{~m}$

2. $6 \mathrm{~m} \times 3 \mathrm{~m} \times 3 \mathrm{~m}$

3. $6 \mathrm{~m} \times 6 \mathrm{~m} \times 3 \mathrm{~m}$

4. $9 \mathrm{~m} \times 6 \mathrm{~m} \times 9 \mathrm{~m}$

5. $9 \mathrm{~m} \times 9 \mathrm{~m} \times 9 \mathrm{~m}$

6. $12 \mathrm{~m} \times 9 \mathrm{~m} \times 9 \mathrm{~m}$

7. $12 \mathrm{~m} \times 12 \mathrm{~m} \times 9 \mathrm{~m}$.

The statistical parameters of gold grade in merged block models for the first stockpile image can be seen in Table 3. In particular, two variances are presented:

- the experimental variance, calculated from all data, which decreases by increasing the block size;
- the theoretical variance, calculated considering only the block size $3 \mathrm{~m} \times 3 \mathrm{~m} \times 3 \mathrm{~m}$ and dividing it by the volume rate at each block size step.

As an example, for the block model $n^{\circ} 3(6 \mathrm{~m} \times 6 \mathrm{~m} \times$ $3 \mathrm{~m})$, the numerical calculations of experimental and theoretical variances are:

- experimental variance: 0.0076 (obtained by the Monte Carlo Simulation, with defined position of the blocks);

- theoretical variance: ratio between the experimental variance of model $\mathrm{n}^{\circ} 1(3 \mathrm{~m} \times 3 \mathrm{~m} \times 3 \mathrm{~m})$, calculated over the original data, and the volume rate of model $\mathrm{n}^{\circ} 3$. Numerically, the theoretical variance value is obtained by: $0.0284 / 4=0.0071$.

From Table 3, the following points can be deduced:

Skewness and kurtosis of the merged block models show that as the block sizes, or reclaimed ore tonnage, increase, the grade distribution function of the stockpile approaches the normal distribution function. In other words, when block size increases, the distribution becomes more and more normal. In order to view the shape of their distributions, the histograms of these averages are created, which can be seen in Figure 3. The profile of the bars is looking more bell-shaped; therefore, we can say that the average grade of material reclaimed

Table 2. Statistical characteristics of 15 simulations of Au grade in a $3 \mathrm{~m} \times 3 \mathrm{~m} \times 3 \mathrm{~m}$ stockpile

\begin{tabular}{|l|l|l|l|l|l|l|}
\hline Simulation & Mean & Variance & Skewness & Kurtosis & Min & Max \\
\hline 1 & 0.308632 & 0.028498 & -0.12527 & 1.824330 & 0.004 & 0.594 \\
\hline 2 & 0.310799 & 0.028403 & -0.19236 & 1.821698 & 0.004 & 0.594 \\
\hline 3 & 0.312075 & 0.029256 & -0.16410 & 1.808189 & 0.004 & 0.594 \\
\hline 4 & 0.312125 & 0.027876 & -0.16013 & 1.827763 & 0.004 & 0.594 \\
\hline 5 & 0.308269 & 0.028875 & -0.13760 & 1.834163 & 0.004 & 0.594 \\
\hline 6 & 0.308495 & 0.028440 & -0.13231 & 1.809922 & 0.004 & 0.594 \\
\hline 7 & 0.305863 & 0.028126 & -0.13376 & 1.811596 & 0.004 & 0.594 \\
\hline 8 & 0.305414 & 0.027807 & -0.09661 & 1.798413 & 0.004 & 0.594 \\
\hline 9 & 0.309183 & 0.027664 & -0.16313 & 1.851235 & 0.004 & 0.594 \\
\hline 10 & 0.304793 & 0.027923 & -0.11151 & 1.807980 & 0.004 & 0.594 \\
\hline 11 & 0.310599 & 0.028596 & -0.14976 & 1.812064 & 0.004 & 0.594 \\
\hline 12 & 0.302026 & 0.028601 & -0.10723 & 1.779780 & 0.004 & 0.594 \\
\hline 13 & 0.309784 & 0.029151 & -0.12937 & 1.788000 & 0.004 & 0.594 \\
\hline 15 & 0.310232 & 0.028379 & -0.13093 & 1.804235 & 0.004 & 0.594 \\
\hline
\end{tabular}

Table 3. Statistical parameters of Au in merged block models for the first stockpile image

\begin{tabular}{|l|l|l|l|l|l|l|l|l|}
\hline $\begin{array}{l}\text { Block size } \\
\left(\mathbf{m}^{\mathbf{3}}\right)\end{array}$ & $\begin{array}{l}\text { Volume rate } \\
(\mathbf{n} . \text { of blocks) }\end{array}$ & Mean & $\begin{array}{l}\text { Experimental } \\
\text { Variance }\end{array}$ & Skewness & Kurtosis & Min & Max & $\begin{array}{l}\text { Theoretical } \\
\text { variance }\end{array}$ \\
\hline $3 \times 3 \times 3$ & 1 & 0.3097 & 0.0284 & -0.1338 & 1.8176 & 0.0040 & 0.5940 & 0.0284 \\
\hline $6 \times 3 \times 3$ & 2 & 0.3098 & 0.0147 & -0.0540 & 2.4966 & 0.0070 & 0.5930 & 0.0142 \\
\hline $6 \times 6 \times 3$ & 4 & 0.3092 & 0.0076 & +0.1074 & 2.7989 & 0.0673 & 0.5683 & 0.0071 \\
\hline $9 \times 6 \times 9$ & 18 & 0.3097 & 0.0017 & -0.1945 & 4.1405 & 0.1279 & 0.4214 & 0.0016 \\
\hline $9 \times 9 \times 9$ & 27 & 0.3098 & 0.0010 & +0.2437 & 3.4921 & 0.2286 & 0.4015 & 0.0011 \\
\hline $12 \times 9 \times 9$ & 36 & 0.3092 & 0.0008 & +0.3679 & 3.7042 & 0.2286 & 0.3905 & 0.0008 \\
\hline $12 \times 12 \times 9$ & 48 & 0.3091 & 0.0006 & +0.1996 & 2.2165 & 0.2638 & 0.3634 & 0.0006 \\
\hline
\end{tabular}



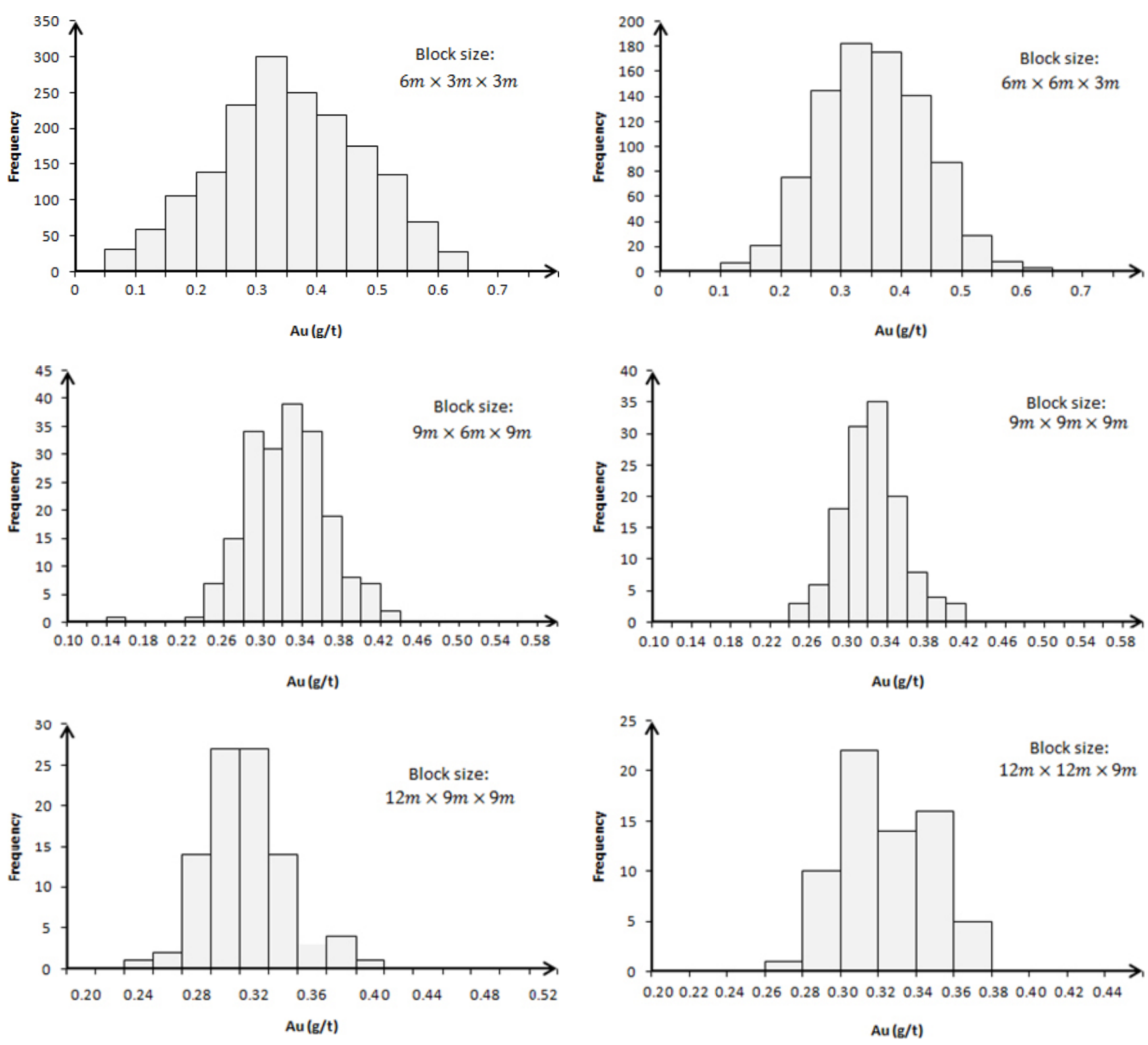

Figure 3: Histogram of merged block grades in the gold stockpile for different block sizes (first image)

from the stockpile in each period has a normal distribution function based on qualitative estimation (not by hypothesis testing).

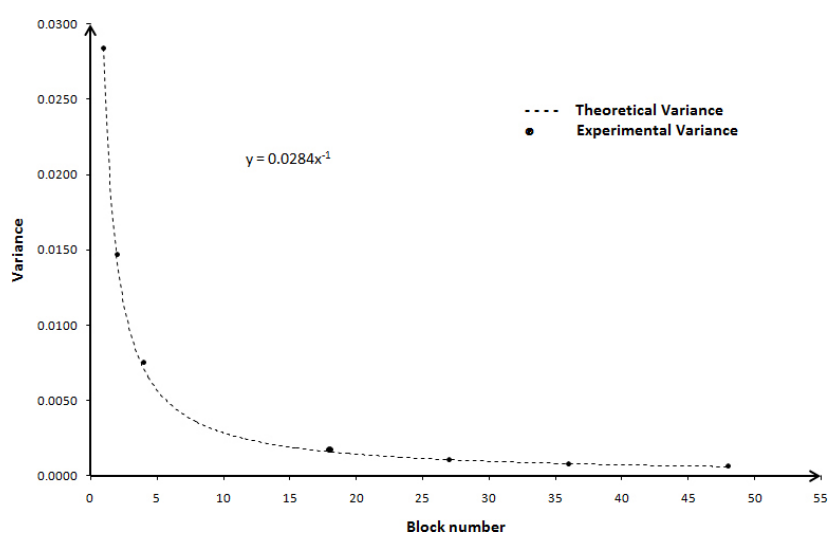

Figure 4: Experimental and theoretical variances of gold grade versus the number of blocks
As the block size increases, the spread of the distribution decreases. Figure 4 shows the experimental and theoretical variances of gold grade versus block number.

Experimental and theoretical variances are similar, which is validated by a very small result of root mean square error (RMSE) among them, equal to 0.00026754 .

As was expected, as the number of blocks, or the reclaimed ore tonnage, increases, the spread of the distribution functions approaches zero.

\section{Case study 2: An open pit iron ore mine}

The second case study is an iron mine (open pit). The final pit contains 251,475 blocks whose dimensions are $5 \mathrm{~m} \times 5 \mathrm{~m} \times 5 \mathrm{~m}$. It assumed that excess materials with a grade of more than $15.0 \%$ and less than $0.6 \%$ will be sent to the low-grade stockpile. The grade distribution histogram of $\mathrm{Fe}$ in the original block model for $15.0 \%<$ $\mathrm{Fe}<30.0 \%$ can be seen in Figure 5. 
The low-grade stockpile in this mine contains 10,000 blocks with the dimensions $5 \mathrm{~m} \times 5 \mathrm{~m} \times 5 \mathrm{~m}$ in three benches with a $5 \mathrm{~m}$ height. The sizes of the seven block models are determined as:

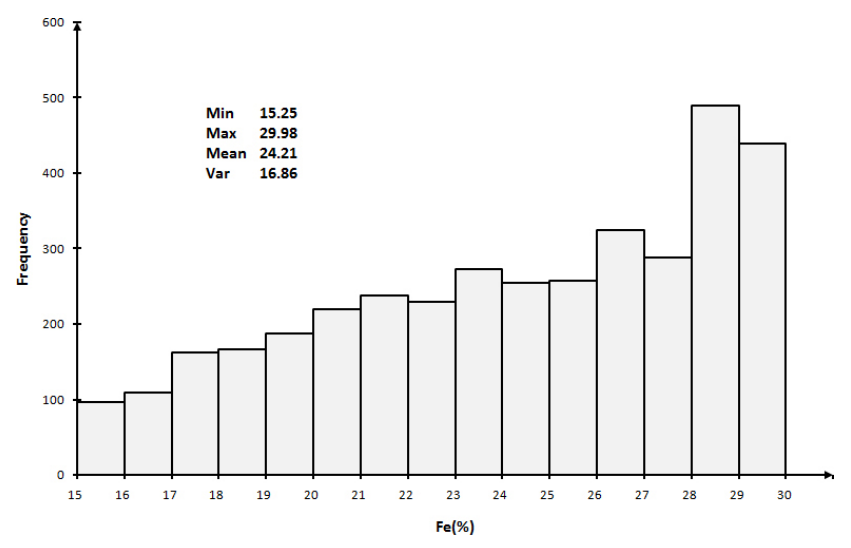

Figure 5: Histogram of iron grade blocks for $15 \%<\mathrm{Fe}<30 \%$ in the orebody

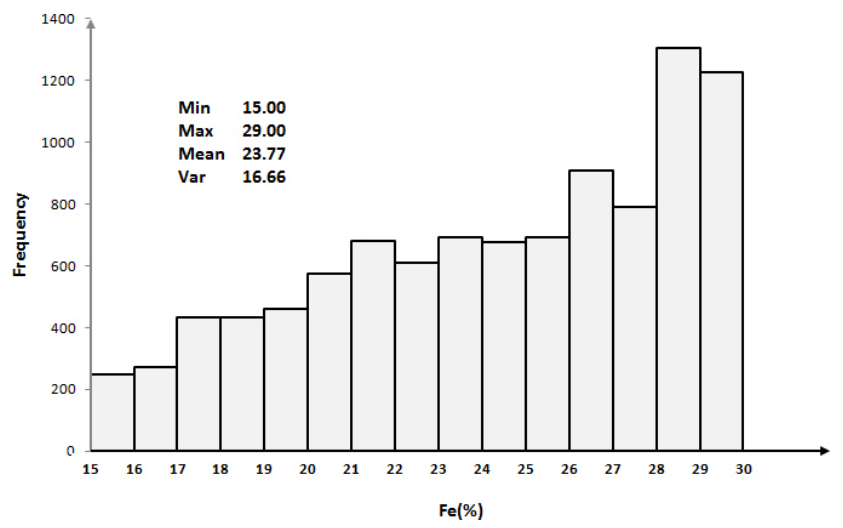

Figure 6: Histogram of iron grade blocks in the stockpile for the first simulation
1. $5 \mathrm{~m} \times 5 \mathrm{~m} \times 5 \mathrm{~m}$

2. $10 \mathrm{~m} \times 5 \mathrm{~m} \times 5 \mathrm{~m}$

3. $10 \mathrm{~m} \times 10 \mathrm{~m} \times 5 \mathrm{~m}$

4. $10 \mathrm{~m} \times 10 \mathrm{~m} \times 10 \mathrm{~m}$

5. $15 \mathrm{~m} \times 15 \mathrm{~m} \times 10 \mathrm{~m}$

6. $20 \mathrm{~m} \times 20 \mathrm{~m} \times 10 \mathrm{~m}$

7. $30 \mathrm{~m} \times 30 \mathrm{~m} \times 10 \mathrm{~m}$.

The grade distribution function of Fe for the first simulation can be seen in Figure 6. The statistical characteristics of the Fe grade for five Monte Carlo simulations are summarized in Table 4.

The statistical parameters of Fe grade in merged block models along with the theoretical variance and Root Mean Square Error (RMSE) for the first stockpile image can be seen in Table 5.

RMSE among experimental and theoretical variance is 0.071248 . The histograms of the averages can be seen in Figure 7. The profile of the bars is looking more bell shaped than the grade distribution function of Figure 6.

Figure 8 also shows the experimental and theoretical variances of Fe grade versus block number.

\section{Modelling of variance behaviour}

A power model approximates the variance behaviour in both cases of iron and gold stockpiles quite well. Increasing the volume rate (by merging the blocks) causes a decrease in the variance. By setting a threshold of variance, it is possible to define an acceptable volume of material, for further stockpile extraction.

As mentioned before, the ore tons sent to the mill were modelled by merging adjoining blocks, but it is possible to send the material from different parts of stockpile. In the next step, it is assumed that blocks can

Table 4: Statistical characteristics of 5 simulations of Fe grade in a $5 \mathrm{~m} \times 5 \mathrm{~m} \times 5 \mathrm{~m}$ stockpile

\begin{tabular}{|l|l|l|l|l|l|l|}
\hline Simulation & Mean & Variance & Skewness & Kurtosis & Min & Max \\
\hline 1 & 23.7676 & 16.6584 & -0.4362 & 2.0483 & 15 & 29 \\
\hline 2 & 23.6802 & 16.8697 & -0.4151 & 2.0204 & 15 & 29 \\
\hline 3 & 23.6325 & 16.9506 & -0.3844 & 1.9878 & 15 & 29 \\
\hline 4 & 23.7214 & 16.6434 & -0.4163 & 2.0351 & 15 & 29 \\
\hline 5 & 23.6814 & 16.6319 & -0.4037 & 2.0043 & 15 & 29 \\
\hline
\end{tabular}

Table 5: Statistical parameters of Fe in merged block models for the first stockpile image

\begin{tabular}{|l|l|l|l|l|l|l|l|l|}
\hline Block size $\left.\mathbf{( m}^{\mathbf{3}}\right)$ & $\begin{array}{l}\text { Volume rate } \\
(\mathbf{n .} \text { of blocks) }\end{array}$ & Mean & $\begin{array}{l}\text { Experimental } \\
\text { Variance }\end{array}$ & Skewness & Kurtosis & Min & Max & $\begin{array}{l}\text { Theoretical } \\
\text { variance }\end{array}$ \\
\hline $5 \times 5 \times 5$ & 1 & 23.7676 & 16.6584 & -0.4362 & 2.0483 & 15.00 & 29.00 & 16.6584 \\
\hline $10 \times 5 \times 5$ & 2 & 23.7676 & 8.3563 & -0.3146 & 2.5081 & 15.50 & 29.00 & 8.3292 \\
\hline $10 \times 10 \times 5$ & 4 & 23.7676 & 4.1528 & -0.2470 & 2.8491 & 16.75 & 28.75 & 4.1646 \\
\hline $10 \times 10 \times 10$ & 8 & 23.7676 & 2.1778 & -0.2201 & 2.9281 & 18.88 & 27.63 & 2.0823 \\
\hline $15 \times 15 \times 10$ & 18 & 23.7453 & 1.0524 & -0.3363 & 3.6754 & 19.00 & 26.11 & 0.9255 \\
\hline $20 \times 20 \times 10$ & 32 & 23.7735 & 0.5339 & 0.1931 & 3.2075 & 22.06 & 26.38 & 0.5206 \\
\hline $30 \times 30 \times 10$ & 72 & 23.7772 & 0.3275 & 0.2736 & 3.0179 & 22.63 & 25.79 & 0.2314 \\
\hline
\end{tabular}



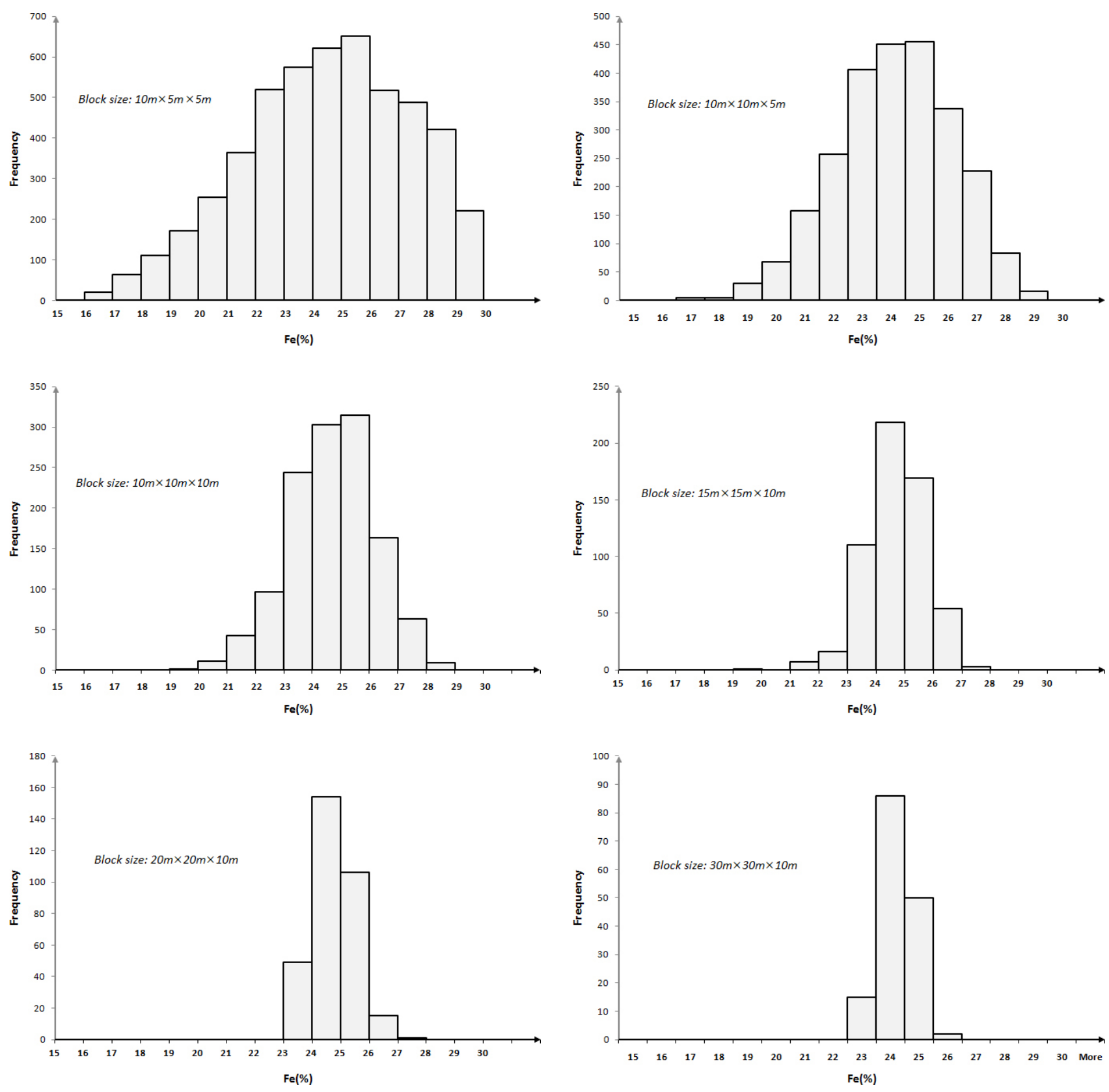

Figure 7: Histogram of merged block grades in the iron stockpile for different block size (first image)

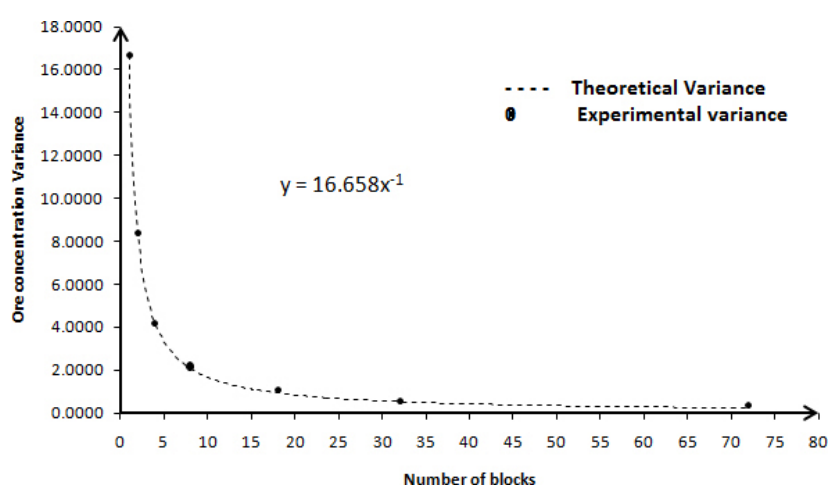

Figure 8: Experimental and theoretical variances of Fe grade versus number of blocks. be taken out from different parts of stockpile, as a result, all possible combinations of blocks extracting from the stockpile should be considered. The number of possible combinations of blocks in a stockpile case study increases exponentially with the volume, and this affects the calculation speed of experimental variance and the practical possibility to get it. For this reason, for the present case studies of gold and iron ore stockpiles, a collection of 50 data points was chosen. The data were selected by an iterative automatic procedure, which allowed finding, with a relatively low number of iterations, a possible combination of 50 data points respecting the same values of the main parameters of distribution function of the whole data set: mean, variance, minimum and maxi- 
mum. For the 50 data points of gold and iron ore stockpiles, the experimental variance has therefore been calculated for the following volume rates.

For gold:

1. $3 \mathrm{~m} \times 3 \mathrm{~m} \times 3 \mathrm{~m}$

2. $3 \mathrm{~m} \times 3 \mathrm{~m} \times 6 \mathrm{~m}$

3. $3 \mathrm{~m} \times 3 \mathrm{~m} \times 9 \mathrm{~m}$

4. $3 \mathrm{~m} \times 3 \mathrm{~m} \times 12 \mathrm{~m}$

5. $3 \mathrm{~m} \times 3 \mathrm{~m} \times 15 \mathrm{~m}$

For iron:

1. $5 \mathrm{~m} \times 5 \mathrm{~m} \times 5 \mathrm{~m}$

2. $5 \mathrm{~m} \times 5 \mathrm{~m} \times 10 \mathrm{~m}$

3. $5 \mathrm{~m} \times 5 \mathrm{~m} \times 15 \mathrm{~m}$

4. $5 \mathrm{~m} \times 5 \mathrm{~m} \times 20 \mathrm{~m}$

5. $5 \mathrm{~m} \times 5 \mathrm{~m} \times 25 \mathrm{~m}$

The results are presented in Table 6 (gold stockpile) and Table 7 (iron stockpile).

A non-linear regression was applied on the experimental variance values. The result was a power behaviour, approximating a hyperbole with coefficients very proxy to the ones obtained by the analysis on MCS images (see Figure 9 for $\mathrm{Au}$ and Figure 10 for $\mathrm{Fe}$ ).

Table 8 reports the coefficients of the power model (slope and power) for both stockpiles of gold and iron. Two cases - regular theoretical position of the blocks (see Figures 4 and 8) and undefined position of the blocks (see Figures 9 and 10) - are presented and compared.

Comparing the coefficients reported in Table 8 confirms that considering the stochastic nature of the stockpile, with an undefined position of the blocks, provides a variance behaviour similar to the one obtained by using defined positions of the blocks. This achievement proves that it is possible to insert the stockpile stochastic formulation inside the chance-constrained programming model.

\subsection{Chance-constrained programming model considering a stockpile}

The long-term production scheduling problem is considered by using a single stockpile. In this section, the deterministic variant of this problem is firstly formulated

Table 6. Result of the variance calculation for different block sizes for the gold stockpile

\begin{tabular}{|l|l|l|l|l|}
\hline Block size $\left.\mathbf{( m}^{3}\right)$ & volume rate & Number of data & Experimental mean & Experimental variance \\
\hline $3 \times 3 \times 3$ & 1 & 50 & 0.3229 & 0.0285 \\
\hline $3 \times 3 \times 6$ & 2 & 1,225 & 0.3229 & 0.0139 \\
\hline $3 \times 3 \times 9$ & 19,600 & 0.3229 & 0.0091 \\
\hline $3 \times 3 \times 12$ & 3 & 230,300 & 0.3229 & 0.0067 \\
\hline $3 \times 3 \times 15$ & 4 & $2,118,760$ & 0.3229 & 0.0052 \\
\hline
\end{tabular}

Table 7. Result of the variance calculation for different block sizes for the iron stockpile

\begin{tabular}{|l|l|l|l|l|}
\hline Block size $\left.\mathbf{( m}^{3}\right)$ & volume rate & Number of data & Experimental mean & Experimental variance \\
\hline $5 \times 5 \times 5$ & 1 & 50 & 24.3200 & 16.0976 \\
\hline $5 \times 5 \times 10$ & 2 & 1,225 & 24.3200 & 7.8845 \\
\hline $5 \times 5 \times 15$ & 3 & 19,600 & 24.3200 & 5.1469 \\
\hline $5 \times 5 \times 20$ & 4 & 230,300 & 24.3200 & 3.7780 \\
\hline $5 \times 5 \times 25$ & $2,118,760$ & 24.3200 & 2.9567 \\
\hline
\end{tabular}

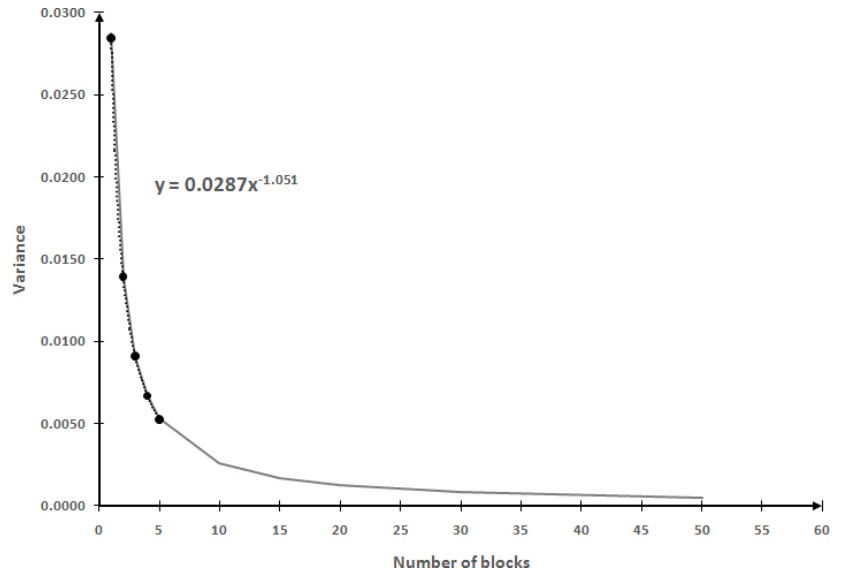

Figure 9: Quasi-hyperbolic behaviour of experimental variances for the Au stockpile

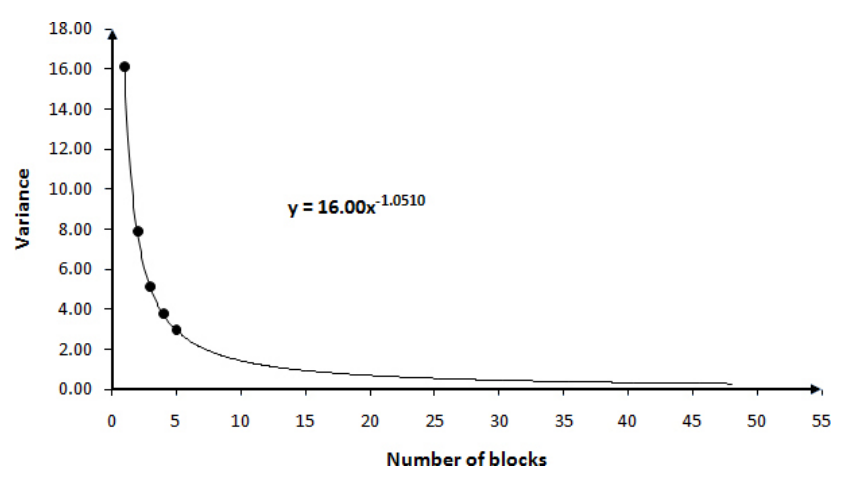

Figure 10: Quasi-hyperbolic behaviour of experimental variances for the Fe stockpile 
Table 8: Coefficients of the power model for the two case studies

\begin{tabular}{|l|l|l|l|l|}
\hline \multirow{2}{*}{ Case study } & \multicolumn{2}{|l|}{ Slope } & Power \\
\cline { 2 - 5 } & $\begin{array}{l}\text { Defined positions } \\
\text { of the blocks }\end{array}$ & $\begin{array}{l}\text { Undefined positions } \\
\text { of the blocks }\end{array}$ & $\begin{array}{l}\text { Defined positions } \\
\text { of the block }\end{array}$ & $\begin{array}{l}\text { Undefined positions } \\
\text { of the block }\end{array}$ \\
\hline Gold stockpile & 0.0284 & 0.0287 & -1.0000 & -1.0510 \\
\hline Iron stockpile & 16.6580 & 16.0000 & -1.0000 & -1.0510 \\
\hline
\end{tabular}

as an Integer Linear Program (ILP). Afterwards, a stochastic variant of this problem is considered, where the average grade of ore sent from stockpile to processing plant is subjected to uncertainty. Finally, the chanceconstrained programming formulation studied in the present paper is introduced.

\subsubsection{Deterministic formulation}

The objective is to schedule production for an open pit mine with a single stockpile over a planning horizon involving $T$ periods. All problem parameters are assumed to be deterministically known at the time when the production plan is built. Three destinations are considered for a block:

- the processing plant, destination of the high-grade ore for subsequent processing;

- the stockpile, destination of the low-grade material;

- a waste dump, destination of the blocks containing no valuable material.

The following notations are introduced:

$i$ : block index $(I=1,2, \ldots, I)$ and $I$ is the total number of blocks to be scheduled;

$j$ : block index $(j=1,2, \ldots J)$ for blocks that can be considered for stockpiling, and $J$ is the total number of blocks that are going to be sent to the stockpile;

$t$ : scheduling time period $(t=1,2, \ldots, T)$ and $T$ is the maximum number of scheduling periods;

$k$ : the counter for block $k \in \Gamma_{i} . \Gamma_{i}$ is the set of block indices defined for block $i$. It consists of the indices of all blocks that need to be removed before extracting block $i$, due to the maximum pit slope angle;

$p_{i}^{t}$ : the NPV resulting from mining of block $i$ during period $t$. It is expressed in Equation 1:

$$
p_{i}^{t}=\frac{T O_{i} \times\left[g_{i} \times R \times\left(p_{r}-c_{m}\right)-p_{c}-c_{e}\right]}{(1+r)^{t}}-\frac{c_{e} \times T W_{i}}{(1+r)^{t}}
$$

Where:

TO: : the total tonnes of ore material in block $I$;

$T W_{i}$ : the total tons of waste material in block $I$;

$\mathrm{g}_{\mathrm{i}}:$ the grade of block $i$.

$R$ : total metal recovery.

$p_{r}$ : unit selling price of recovered metal.

$c_{m}$ : unit smelting and selling cost of recovered metal.

$p_{c}$ : unit processing cost of ore.

$c_{e}$ : unit cost of mining rock.

$r$ : economic discount rate in each period.
If block $i$ is extracted in period $t$ but sent to the stockpile, the generated NPV in period $t\left(p_{i}^{\prime t}\right)$ can be calculated with Equation 2:

$$
p_{i}^{\prime t}=\frac{-c_{e}^{\prime} \times T O_{i}}{(1+r)^{t}}
$$

Where:

$c_{e}$ ': unit cost of mining and sending the materials to the stockpile.

$p_{s}^{t}$ : the NPV resulting from re-handling and processing one ton of stockpiled material in period $t$ with respect to the grade models; it is formulated in Equation 3:

$$
p_{s}^{t}=\frac{g_{s} \times R \times\left(p_{r}-c_{m}\right)-p_{c}-c_{r e}}{(1+r)^{t}}
$$

Where:

$g_{s}$ : the grade of material leaving the stockpile;

$c_{r e}$ : unit cost of re-handling and sending the materials from stockpile to the processing plant;

$R C_{\text {max }}^{t}$ : maximum mining capacity in period $t$;

$R C_{\text {min }}^{t}$ : minimum amount of ore and waste that should be mined in period $t$;

$g_{\text {max }}^{t}$ : the maximum acceptable average grade of ore sent to the processing plant in period $t$;

$g_{\text {min }}^{t}:$ the minimum acceptable average grade of ore sent to the processing plant in period $t$;

$T O_{\text {min }}^{t}$ : minimum amount of ore that should be removed in period $t$;

$T O_{\text {max }}^{t}$ : maximum processing capacity in period $t$;

$I^{0}:$ the amount of stockpiled materials at the beginning of period 1;

TCS: the total capacity of stockpile;

$x_{i}^{t}$ : a binary integer variable which takes the value of 1 if block $i$ is mined during period $t$ and 0 otherwise;

$y_{i}^{t} \in[0,1]$ : a continuous variable, representing the portion of block $i$ sent to the stockpile in period $t$;

$z^{t}$ : the amount of material reclaimed from the stockpile and sent to the processing plant during the period $t$;

$I^{t}$ : the amount of material in the stockpile at the end of period $t$.

Objective function: The mine schedule can be optimized with respect to a number of factors. The criterion of optimality can be either maximizing the Net Present Value (NPV), minimizing mining costs, minimizing the variance of the grade (Chanda and Ricciardone, 2002), minimizing the deviation from production targets (Dimitrakopoulos and Ramazan, 2004), etc.; however, the 
most commonly used criterion in long term scheduling optimization is to maximize $N P V$. In this paper, the expected $N P V$ is maximized by the objective function presented in Equation 4:

$$
\operatorname{Max} Z=\left[\sum_{t=1}^{T} \sum_{i=1}^{I} p_{i}^{t} \times x_{i}^{t}\right]-\left[\sum_{t=1}^{T} \sum_{j=1}^{J}\left(p_{j}^{t}-p^{t}{ }_{j}\right) \times y_{j}^{t}\right]+\left[\sum_{t=1}^{T}\left(p_{s}^{t} \times z^{t}\right)\right]
$$

Where $\mathrm{Z}$ is the variable representing NPV

The objective function presented in Equation 4 includes three different parts:

- the first part evaluates the $N P V$ to be generated if all the extracted ore blocks are sent to the processing plant;

- the second part gives the $N P V$ of sending ore to the stockpile;

- the third part adds the generated $N P V$ due to the processing of $z^{t}$ tons of ore material taken from the stockpile.

Grade blending constraints: The average grade of ore sent from the mine and the stockpile to the processing plant should be less than an upper bound $\left(g_{\max }^{t}\right)$ and more than a lower bound $\left(g_{\text {min }}^{t}\right)$ for each scheduling period, $t$. The grade blending constraints are presented in Inequality 5 (upper bound) and Inequality 6 (lower bound).

$$
\begin{gathered}
\frac{\left.\left(\sum_{i=1}^{I} g_{i} \times T O_{i} \times x_{i}^{t}\right)\right)-\left(\sum_{j=1}^{J} g_{j} \times T O_{j} \times y_{j}^{t}\right)+\left(g_{s} \times z^{t}\right)}{\left.\left(\sum_{i=1}^{I} T O_{i} \times x_{i}^{t}\right)\right)-\left(\sum_{j=1}^{J} T O_{j} \times y_{j}^{t}\right)+z^{t}} \leq g_{\max }^{t} \quad \forall t \\
\frac{\left(\sum_{i=1}^{I} g_{i} \times T O_{i} \times x_{i}^{t}\right)-\left(\sum_{j=1}^{J} g_{j} \times T O_{j} \times y_{j}^{t}\right)+\left(g_{s} \times z^{t}\right)}{\left(\sum_{i=1}^{I} T O_{i} \times x_{i}^{t}\right)-\left(\sum_{j=1}^{J} T O_{j} \times y_{j}^{t}\right)+z^{t}} \geq g_{\min }^{t} \quad \forall t
\end{gathered}
$$

The above equations can be rewritten as follows (Inequality 7 and Inequality 8):

$$
\begin{gathered}
\sum_{i=1}^{I}\left(g_{i}-g_{\text {max }}^{t}\right) \times T O_{i} \times x_{i}^{t}-\sum_{j=1}^{J}\left(g_{j}-g_{\text {max }}^{t}\right) \times \\
\times T O_{j} \times y_{j}^{t}+\left(g_{s}-g_{\text {max }}^{t}\right) \times z^{t} \leq 0 \quad \forall t \\
\sum_{i=1}^{I}\left(g_{i}-g_{\text {min }}^{t}\right) \times T O_{i} \times x_{i}^{t}-\sum_{j=1}^{J}\left(g_{j}-g_{\text {min }}^{t}\right) \times \\
\quad \times T O_{j} \times y_{j}^{t}+\left(g_{s}-g_{\text {min }}^{t}\right) \times z^{t} \geq 0 \quad \forall t
\end{gathered}
$$

Processing capacity constraints: The total tons of ore processed in each period should be less than an upper bound $\left(T O^{t}\right.$ max $)$ and more than a lower bound $\left(T O_{\text {min }}^{t}\right)$ for each time period, $t$. The processing capacity constraints are presented in Inequality 9 (upper bound) and Inequality 10 (lower bound).

$$
\begin{aligned}
& \left(\sum_{i=1}^{I} T O_{i} \times x_{i}^{t}\right)-\left(\sum_{j=1}^{J} T O_{j} \times y_{j}^{t}\right)+z^{t} \leq T O_{\max }^{t} \quad \forall t \\
& \left(\sum_{i=1}^{I} T O_{i} \times x_{i}^{t}\right)-\left(\sum_{j=1}^{J} T O_{j} \times y_{j}^{t}\right)+z^{t} \geq T O_{\min }^{t} \quad \forall t
\end{aligned}
$$

Stockpiling constraints: These constraints balance the material flow at each stockpile. The amount of ore left in the stockpile at the end of period $t$ is equal to the amount of ore sent to the stockpile during period $t$, minus the amount of ore taken from the stockpile during $t$ plus the amount of ore left in the stockpile at the end of the previous period. The stockpiling constraint for period 1 is presented in Equation 11, while for other periods is shown in Equation 12.

$$
\begin{gathered}
I^{1}=\left(\sum_{j=1}^{J} T O_{j} \times y_{j}^{1}\right)-z^{1}+I^{0} \\
I^{t}=\left(\sum_{j=1}^{J} T O_{j} \times y_{j}^{t}\right)+I^{t-1}-z^{t} \quad \forall t=2,3, \ldots T
\end{gathered}
$$

Due to the limited capacity of the stockpile, the amount of ore left in the stockpile at the end of each period should be limited (Inequality 13):

$$
I^{t} \leq T C S \quad \forall t
$$

The amount of ore sent from the stockpile to the processing plant in each time period should be less than or equal to the inventory at the end of the previous period (Inequality 14):

$$
I^{t-1} \geq z^{t} \quad \forall t
$$

Mining capacity constraints: Due to the limited mining capacity, the total tons of rock (waste and ore) to be mined should be less than an upper bound $\left(R C^{t}{ }_{\max }\right)$. In order to balance waste production throughout the scheduling horizon, a lower bound $\left(R C_{\text {min }}^{t}\right)$ also may be needed. The mining capacity constraints are presented in Inequality 15 (upper bound) and Inequality 16 (lower bound):

$$
\begin{aligned}
& \sum_{i=1}^{I}\left(T O_{i}+T W_{i}\right) \times x_{i}^{t} \leq R C_{\max }^{t} \quad \forall t \\
& \sum_{i=1}^{I}\left(T O_{i}+T W_{i}\right) \times x_{i}^{t} \geq R C_{\min }^{t} \quad \forall t
\end{aligned}
$$

Slope constraints: These constraints ensure that all blocks that directly restrict the mining of a given block $b$ must be completely mined out before the mining of the block $i$ start (Inequality 17): 


$$
x_{i}^{t}-\sum_{\tau=1}^{t} x_{k}^{\tau} \leq 0 \quad \forall i, k \in \Gamma_{i}, t
$$

Reserve constraints: Reserve constraints ensure that any block in the model can be mined only once (Inequality 18):

$$
\sum_{t=1}^{T} x_{i}^{t} \leq 1 \quad \forall i
$$

Linkage constraints: Each block must first be extracted and then processed (Inequality 19):

$$
x_{i}^{t} \geq y_{i}^{t} \quad \forall i, t
$$

Decision variables bounds: They refer to the variables $x_{i}^{t}$ (Equation 20), $y_{i}^{t}$ (Inequality 21), $I_{t}$ and $z_{t}$ (Inequality 22)

$$
\begin{gathered}
x_{i}^{t}=0 \text { or } 1 \quad \forall i, t \\
0 \leq y_{i}^{t} \leq 1 \quad \forall i, t \\
I^{t}, z^{t} \geq 0 \quad \forall t
\end{gathered}
$$

\subsubsection{Stochastic formulation}

Stochastic programming is a well-established method in operations research for modelling optimization problems that involve statistically calculated uncertainty. In this framework, the probability distributions governing the uncertain data are known or can be estimated. The goal is to find some policy feasible for all (or almost all) the possible parameter realizations and to optimize the expectation of some function of the decisions and the random variables (Shapiro and Philpott, 2007). Among the different possibilities to handle this problem, two approaches are most commonly used: the two-stage stochastic programming method and the chance-constrained stochastic programming method. In the two-stage stochastic programming approach, in the first stage the decision maker is allowed to take decisions, whose outcomes will be affected by the occurrence of a random event afterwards. Negative effects potentially experienced as a result of the first-stage decisions will finally be compensated by a recourse decision in the second stage. In this context, any violation of constraints caused by unexpected random effects can be balanced later on in the second stage. The costs of compensative decisions, when known, are considered as a penalization for the violation of constraints. By using this approach, the stochastic constraints must be satisfied with a probability equal to one (Kall and Wallace, 1994).

Using this first approach may face some issues, since it is common that for some applications, compensations do not exist, while for others they cannot be modelled as costs. In this context, the main target is to safeguard the solution obtained against very bad outcomes, depending mostly on unavoidable extreme events, causing violations of constraints. In these cases, the second approach, the chance-constrained stochastic programming, originally formulated by Charnes et al. (1958) and Charnes and Cooper (1959) and then developed and applied by Charnes and Cooper (1963), must therefore be applied. The following section presents the approach, including the new specificity of stockpile stochastic constraints, useful to handle the uncertainty of block grade in the binary integer model.

Objective function: As is clear due to the stochastic nature of $g_{s}$ in the third part of the objective function (see Equation 4), $Z$ is also a random variable with the expected value (see Equation 23) and standard deviation (see Equation 24):

$$
\begin{gathered}
E[Z]=\left[\sum_{t=1}^{T} \sum_{i=1}^{I} p_{i}^{t} \times x_{i}^{t}\right]- \\
-\left[\sum_{t=1}^{T} \sum_{j=1}^{J}\left(p_{j}^{t}-p^{\prime t}{ }_{j}\right) \times y_{j}^{t}\right]+\left[\sum_{t=1}^{T}\left(E\left[p_{s}^{t}\right] \times z^{t}\right)\right] \\
\sigma(Z)=\left[\sum_{t=1}^{T} \frac{z^{t} \times\left[R \times\left(p_{r}-c_{m}\right)\right]}{(1+r)^{t}}\right] \times \sigma\left(g_{S}\right)
\end{gathered}
$$

Equation 25 presents the expected value of $p_{s}^{t}$ :

$$
E\left[p_{s}^{t}\right]=E\left[g_{s}\right] \times R \times\left(p_{r}-c_{m}\right)-p_{c}-\frac{c_{r e}}{(1+r)^{t}}
$$

On the other hand, $E\left[g_{s}\right]$ and $\sigma\left(g_{s}\right)$ are the expected value and standard deviation of grade of material leaving the stockpile.

Charnes and Cooper (1963) suggested three kinds of objective functions in chance-constrained programming, where the objective is an expectational functional (the E-model), or the variance of some result (the Vmodel), or the probability of some occurrence (such as satisfying the constraints) (the P-model). In this study the objective function is set up for the maximization of expected value of NPV, thus the objective function is expressed by Equation 26:

$$
\begin{aligned}
\operatorname{Max}(E[Z])=\left[\sum_{t=1}^{T} \sum_{i=1}^{I} p_{i}^{t} \times x_{i}^{t}\right]-\left[\sum_{t=1}^{T} \sum_{j=1}^{J}\left(p_{j}^{t}-p_{j}^{\prime^{t}}\right) \times y_{j}^{t}\right]+ \\
+\left[\sum_{t=1}^{T} \frac{E\left[g_{s}\right] \times R \times\left(p_{r}-c_{m}\right)-p_{c}-c_{r e}}{(1+r)^{t}} \times z^{t}\right]
\end{aligned}
$$

Stochastic constraints: As expressed before, among the model constraints, only the grade blending constraints (Inequalities 5 and 6) contain random parameters. The generic way to express the stochastic con- 
straints is presented in Inequality 27 (lower bound) and Inequality 28 (upper bound):

$$
\begin{gathered}
\operatorname{Prob}\left[\frac{\left(\sum_{i=1}^{I} g_{i} \times T O_{i} \times x_{i}^{t}\right)-\left(\sum_{j=1}^{J} g_{j} \times T O_{j} \times y_{j}^{t}\right)+\left(g_{s} \times z^{t}\right)}{\left(\sum_{i=1}^{I} T O_{i} \times x_{i}^{t}\right)-\left(\sum_{j=1}^{J} T O_{j} \times y_{j}^{t}\right)+z^{t}} \leq g_{\max }^{t}\right] \geq \beta_{t} \quad \forall t \\
\operatorname{Prob}\left[\frac{\left(\sum_{i=1}^{I} g_{i} \times T O_{i} \times x_{i}^{t}\right)-\left(\sum_{j=1}^{J} g_{j} \times T O_{j} \times y_{j}^{t}\right)+\left(g_{s} \times z^{t}\right)}{\left(\sum_{i=1}^{t} T O_{i} \times x_{i}^{t}\right)-\left(\sum_{j=1}^{J} T O_{j} \times y_{j}^{t}\right)+z^{t}} \geq g_{\min }^{t}\right] \geq \beta_{t} \quad \forall t
\end{gathered}
$$

$\mathrm{b}_{t}$ is a vector containing a set of values that are probability measures of the extent to which constraints violations are permitted (confidence level).

In the following Equation 29, the average grade of material to be sent to the processing plant during period $t$ is defined as a new variable $u_{t}$ :

$$
\frac{\left(\sum_{i=1}^{I} g_{i} \times T O_{i} \times x_{i}^{t}\right)-\left(\sum_{j=1}^{J} g_{j} \times T O_{j} \times y_{j}^{t}\right)+\left(g_{s} \times z^{t}\right)}{\left(\sum_{i=1}^{I} T O_{i} \times x_{i}^{t}\right)-\left(\sum_{j=1}^{J} T O_{j} \times y_{j}^{t}\right)+z^{t}}=u_{t}
$$

$u_{t}$ is a random variable whose distribution can be approximated by a normal distribution function with the following mean (Equation 30) and standard deviation (Equation 31):

$$
\begin{gathered}
E\left[u_{t}\right]=\frac{\left(\sum_{i=1}^{I} g_{i} \times T O_{i} \times x_{i}^{t}\right)-\left(\sum_{j=1}^{J} g_{j} \times T O_{j} \times y_{j}^{t}\right)+\left(E\left[g_{s}\right] \times z^{t}\right)}{\left(\sum_{i=1}^{I} T O_{i} \times x_{i}^{t}\right)-\left(\sum_{j=1}^{J} T O_{j} \times y_{j}^{t}\right)+z^{t}} \\
\sigma\left(u_{t}\right)=\frac{z^{t} \times \sigma\left(g_{s}\right)}{\left(\sum_{i=1}^{I} T O_{i} \times x_{i}^{t}\right)-\left(\sum_{j=1}^{J} T O_{j} \times y_{j}^{t}\right)+z^{t}}
\end{gathered}
$$

Thus, Inequality 27 can be re-written in Inequality 32:

$$
\operatorname{Prob}\left[u_{t} \leq g_{\max }^{t}\right] \geq \beta_{t}
$$

By subtracting $E(u)$ from both sides of the inequality in the bracket, and dividing it by $\mathrm{s}\left(u_{t}\right)$, Inequality 32 can be re-written as Inequality 33:

$$
\operatorname{Prob}\left[\frac{u_{t}-E\left[u_{t}\right]}{\sigma\left(u_{t}\right)} \leq \frac{g_{\max }^{t}-E\left[u_{t}\right]}{\sigma\left(u_{t}\right)}\right] \geq \beta_{t}
$$

Note that $S u_{t}=\frac{\mathrm{u}_{\mathrm{t}}-\mathrm{E}\left[\mathrm{u}_{\mathrm{t}}\right]}{\sigma\left(\mathrm{u}_{\mathrm{t}}\right)}$ has a standard normal distribution function; as a result, a value of $\mathrm{y}_{\mathrm{b} t}$ can then be determined from the area under standard normal curve such that (Equation 34):

$$
\operatorname{Prob}\left(S u_{t} \leq \psi_{\beta t}\right)=\beta_{\mathrm{t}}
$$

Thus, combining Inequalities 33 and Equation 34, Inequality 35 results in:

$$
\frac{g_{\max }^{t}-E\left[u_{t}\right]}{\sigma\left(u_{t}\right)} \geq \psi_{\beta t} \Rightarrow E\left[u_{t}\right]+\left[\psi_{\beta t} \times \sigma\left(u_{t}\right)\right] \leq g_{\max }^{t}
$$

The two terms can be interpreted as follows:

$\psi_{\beta t} \times \sigma\left(u_{t}\right)$ as a risk term;

$E\left[u_{t}\right]$ as an average term.

Further simplifying the expression, the stochastic constraint of Inequality 27 can be transformed in Inequality 36:

$$
\frac{\left(\sum_{i=1}^{t} g_{i} \times T O_{i} \times x_{i}^{t}\right)-\left(\sum_{j=1}^{J} g_{j} \times T O_{j} \times y_{j}^{t}\right)+\left[E\left[g_{s}\right]+\left(\psi_{\beta_{t}} \times \sigma\left(g_{s}\right)\right)\right] \times z^{t}}{\left(\sum_{i=1}^{t} T O_{i} \times x_{i}^{t}\right)-\left(\sum_{j=1}^{J} T O_{j} \times y_{j}^{t}\right)+z^{t}} \leq g_{\max }^{t}
$$

Similarly, the deterministic equivalent of Inequality $\mathbf{2 8}$ is in the form of Inequality $\mathbf{3 7}$ :

$$
\frac{\left(\sum_{i=1}^{t} g_{i} \times T O_{i} \times x_{i}^{t}\right)-\left(\sum_{j=1}^{J} g_{j} \times T O_{j} \times y_{j}^{t}\right)+\left[E\left[g_{s}\right]+\left(\psi_{\beta i} \times \sigma\left(g_{s}\right)\right)\right] \times z^{t}}{\left(\sum_{i=1}^{t} T O_{i} \times x_{i}^{t}\right)-\left(\sum_{j=1}^{J} T O_{j} \times x_{j}^{t}\right)+z^{t}} \geq g_{\min }^{t}
$$

Such that (Equation 38):

$$
\operatorname{Prob}\left(S u_{t} \leq \psi_{\beta t}^{\prime}\right)=1-\beta_{t}
$$

It is worth noticing that $\psi_{\beta t}>0 \leftrightarrow \beta_{t}<0.5$ and that $\mathrm{y}_{\mathrm{b} t}$ is a coefficient that can be pre-computed. Making $b_{t}$ larger causes $\mathrm{y}_{\mathrm{b} t}$ to become larger, and this makes the stochastic constraints harder to satisfy. With $\beta_{t} \geq 0.5$, then $1-\beta_{t} \leq 0.5$, which means $\psi_{\beta t} \leq 0$. As a result, the feasible region of chance-constrained problems depends on the user's desired confidence level. If a high confidence level is required, the feasible region is small. If the confidence level is lowered, the feasible region becomes larger. Table 9 shows some values of $b_{t}$ and their corresponding values of $\mathrm{y}_{\mathrm{b} t}$.

Table 9: Typical values of $b_{t}$ and the corresponding values of $\mathrm{y}_{b t}$

\begin{tabular}{|l|c|c|c|c|c|c|c|}
\hline$\beta_{t}$ & $50 \%$ & $60 \%$ & $70 \%$ & $80 \%$ & $90 \%$ & $95 \%$ & $96 \%$ \\
\hline$\Psi_{\beta t}$ & 0 & 0.25 & 0.53 & 0.85 & 1.29 & 1.65 & 1.75 \\
\hline
\end{tabular}

As it was seen, the deterministic equivalent form of the chance constrained programming model for production scheduling with a single stockpile is linear.

\section{Results}

To assess the efficiency and practicality of the proposed method, a study was carried out on a small size open pit gold mine that can be mined within 10 years. 


\subsection{Application of the model to an open pit gold mine}

To estimate the quality parameters of the $\mathrm{Au}$, a 3D block model of the gold deposit was prepared and a resource estimation was made using block kriging (e.g., Chiles and Delfiner, 2012). The orebody and surrounding waste materials were discretized into equal sized blocks with a dimension of $6 \mathrm{~m} \times 6 \mathrm{~m} \times 5 \mathrm{~m}$. Then, the minable reserve was determined using the LerchsGrossmann algorithm (Lerchs and Grossman, 1964). The total number of blocks within final pit is 2,690, including waste and ore blocks. The mine has a stockpile capacity of 200,000 tones, and the processing plant has a yearly requirement of 100,000-200,000 tons of ore. In order to classify ore and waste, the mill cut-off grade was set at $0.35 \mathrm{~g} / \mathrm{t} \mathrm{Au}$. The managers decided to store ore blocks whose $\mathrm{Au}$ grade is more than $0.35 \mathrm{~g} / \mathrm{t}$ and less

Table 1o: Parameters for small scale open pit gold mine

\begin{tabular}{|l|l|l|l|}
\hline Description & Value & Description & Value \\
\hline Total ore blocks & 1,676 & $\begin{array}{l}\text { Cut-off grade } \\
\text { (g/t) }\end{array}$ & 0.35 \\
\hline Total waste blocks & 1,014 & $I^{0}$ (tons) & 0 \\
\hline $\begin{array}{l}\text { Block dimensions } \\
(\mathrm{m})\end{array}$ & $6 \times 6 \times 5$ & $\begin{array}{l}\text { Annual discount } \\
\text { rate }\end{array}$ & $10 \%$ \\
\hline Total ore ton & 793,418 & $R C_{\text {max }}^{t}$ (tons) & 300,000 \\
\hline Total waste ton & 480,028 & $R C_{\text {min }}^{t}$ (tons) & 140,000 \\
\hline Mine life (years) & 10 & $\mathrm{~g}_{\text {min }}^{\mathrm{g}}$ (g) $)$ & 1.4 \\
\hline $\begin{array}{l}\text { Duration of each } \\
\text { period (years) }\end{array}$ & 2 & $\mathrm{TO}_{\text {min }}^{\mathrm{t}}$ (tons) & 100,000 \\
\hline Pit slope angle & $45^{0}$ & $\mathrm{TO}_{\text {max }}^{\mathrm{t}}$ (tons) & 200,000 \\
\hline$T C S$ (ton) & 200,000 & $\mathrm{~b}_{t}$ & $90 \%$ \\
\hline
\end{tabular}

Table 11: Statistical parameters of material with $0.35 \leq \mathrm{Au} \leq 1.20$

\begin{tabular}{|l|c|}
\hline Parameter & Value \\
\hline Number of blocks & 810 \\
\hline Tonnage & 383,454 \\
\hline Average grade $(\mathrm{g} / \mathrm{t})$ & 0.8689 \\
\hline Standard deviation $(\mathrm{g} / \mathrm{t})$ & 0.2529 \\
\hline
\end{tabular}

than $1.20 \mathrm{~g} / \mathrm{t}$ in a low-grade stockpile for future blending. The remnant model's details are given in Table $\mathbf{1 0}$.

Statistical parameters of the materials with $0.35 \leq$ $\mathrm{Au} \leq 1.20$ within the original block model are presented in Table 11. In the case study, it is assumed that the gold grade distribution function in the stockpile is the same distribution function of the blocks in the block model that may be sent to the stockpile. This simplification has been possible by the analysis on the stockpile stochastic behaviour presented in Section 2.1.

Production scheduling for the presented case study is done applying GAMS ${ }^{\circledR}$ software. A computer with 8 CPUs and $20 \mathrm{~GB}$ of ram has been used with Windows 7 Professional. The processor is an Intel(R) Core(TM) i7 CPU930@2.80 GHz processor speed, 4Core(s), 8 Logical Processor(s). Two models were run, the first model with no stockpile option (NSM), and the second one with stockpile option (MSM) assuming the maximum possible standard deviation $(0.2529 \mathrm{~g} / \mathrm{t})$. The results of the production scheduling are summarized in Table 12, while Figure 11 shows the quantity of metal content sent to the mill over the production scheduling period for the two models, NSM and MSM. Finally, Figure 12 shows the amount of stockpile content at the end of each scheduling period using MSM model.

By applying Equations 1-3, together with the programming model constraints, the total NPVs generated from NSM and MSM are \$22 million and \$23 million, respectively.

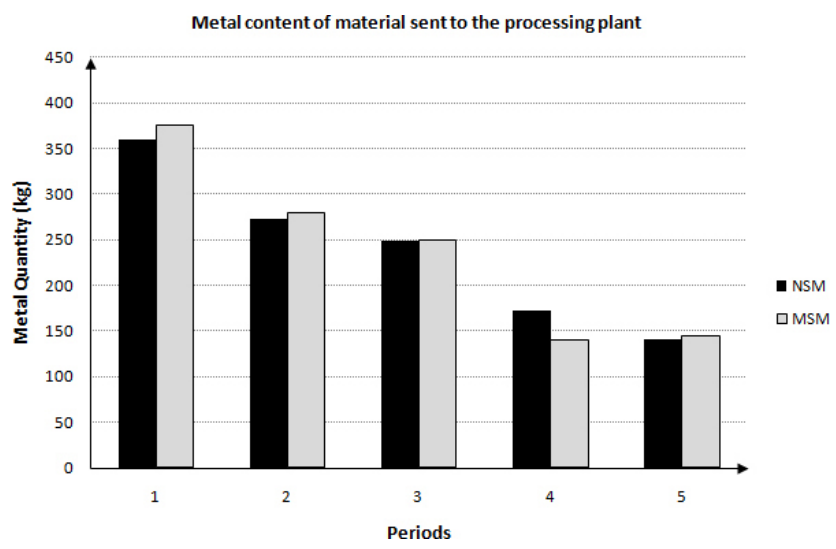

Figure 11: Metal input to the processing plant using NAM and MSM in each period

Table 12. Results of the production scheduling using NSM and MSM.

\begin{tabular}{|c|c|c|c|c|c|c|c|c|c|c|c|c|}
\hline \multirow[t]{2}{*}{ Period } & \multicolumn{2}{|c|}{ Extracted ore ton } & \multicolumn{2}{|c|}{$\begin{array}{l}\text { Extracted waste } \\
\text { ton }\end{array}$} & \multicolumn{2}{|c|}{$\begin{array}{l}\text { Ore ton to } \\
\text { stockpile }\end{array}$} & \multicolumn{2}{|c|}{$\begin{array}{l}\text { Ore ton from } \\
\text { stockpile to mill }\end{array}$} & \multicolumn{2}{|c|}{$\begin{array}{l}\text { Ave. grade of } \\
\text { ore sent to } \\
\text { stockpile }\end{array}$} & \multicolumn{2}{|c|}{$\begin{array}{l}\text { Ave. grade of } \\
\text { ore sent to mill }\end{array}$} \\
\hline & NSM & MSM & NSM & MSM & NSM & MSM & NSM & MSM & NSM & MSM & NSM & MSM \\
\hline 1 & 199,775 & 258,476 & 4,734 & 29,351 & 0 & 58,476 & 0 & 0 & - & 0.59 & 1.80 & 1.87 \\
\hline 2 & 194,567 & 175,158 & 35,032 & 68,170 & 0 & 34,372 & 0 & 58,476 & - & 0.50 & 1.40 & 1.40 \\
\hline 3 & 177,052 & 154,802 & 81,898 & 59,175 & 0 & 10,131 & 0 & 33,686 & - & 0.51 & 1.40 & 1.40 \\
\hline 4 & 121,664 & 99,887 & 159,062 & 157,642 & 0 & 10,704 & 0 & 10,817 & - & 0.43 & 1.42 & 1.40 \\
\hline 5 & 100,361 & 105,095 & 199,301 & 165,690 & 0 & 5,681 & 0 & 3,632 & - & 0.53 & 1.40 & 1.40 \\
\hline Total & 793,418 & 793,418 & 480,028 & 480,028 & $\mathbf{0}$ & 119,364 & $\mathbf{0}$ & 106,611 & - & - & - & - \\
\hline
\end{tabular}




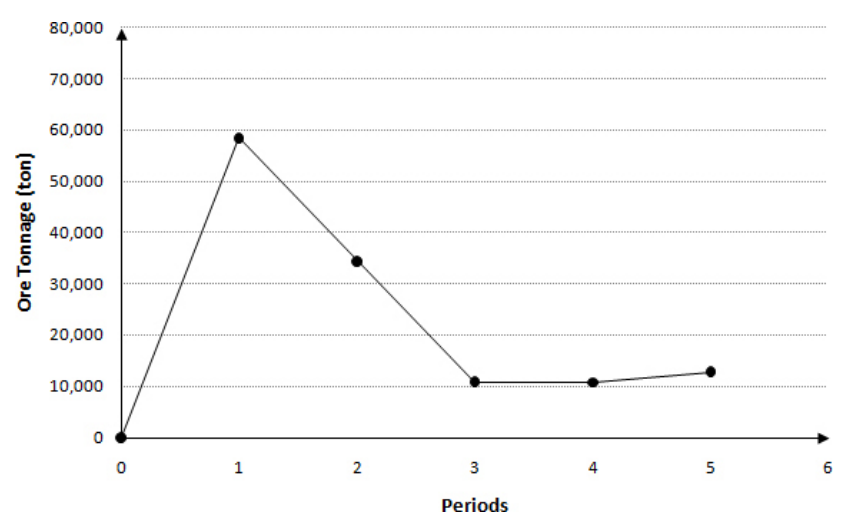

Figure 12: Stockpile content at the end of each scheduling period in MSM

\section{Discussion}

All production constraints are respected throughout the production scheduling period in both of the presented models, NSM and MSM, equal to 793,418 tons after five periods. However, as Table 12 shows, in the first period, the ore production was increased to 258,476 tons for MSM with respect to the 199,775 tons of NSM, in order to provide high grade ore for the processing plant. This was possible by considering the stockpile option during the optimization process.

The effect for MSM was obtaining a higher economic value, mainly due to the higher average grade of ore sent to the mill in the first period. Even including the cost for re-handling the stockpile, MSM still generated a 4.5\% higher NPV than NSM. In fact, the objective function used in MSM allows the early mill head grade to be raised even further, while letting the low-grade material to be sent to the stockpile for future use during the life cycle of the mine. This is evidenced from Figure 11, showing the quantity of metal content sent to the mill over the production scheduling period.

Table 12 also shows an increasing trend in waste removal in both NSM and MSM, obtained by the objective function, which tries to maximize the NPV by differing the waste removal. However, again, for the first phases the wastes in the MSM are higher than NSM because of the tendency of the MSM to extract more ore during the first years of a mine's life. This approach results in waste tailings filled more gradually across time in MSM than in NSM.

Finally, by analysing Figure 12, the stockpile capacity constraint $(200,000$ tons) included in MSM was respected for each scheduling period, evidencing new possibilities for further material storage.

\section{Conclusion}

A new stochastic chance-constraint model was developed for long-term production scheduling of open pit mines considering a single stockpile option.
The work has demonstrated that homogenization does not occur completely in long-term stockpiles. In fact, the average grade of material leaving the stockpile can be supposed to be a random variable with a normal distribution function, whose mean and maximum standard deviation are the mean and standard deviation of the stored materials, respectively. Therefore, the probabilistic form of the open pit long-term production scheduling (OPLTPS) model contains a stochastic objective function and a series of deterministic and stochastic constraints. The stochastic objective function and constraints could not to be handled directly in the optimization process; consequently, a deterministic form of the model was obtained. This process leads to converting stochastic linear equations to the deterministic linear equivalents.

The proposed method, by the aid of GAMS ${ }^{\circledR}$ software, was applied to an open pit gold mine as the case study. For the specific project, the overall NPV was calculated to increase by about $4.5 \%$ with respect to not using the stochastic stockpile. The results have shown better profitability in the long-range because the objective function has forced the model to send high-grade materials to the mill in the early phases of production planning, while forward low-grade ore to the stockpile for future processing. The proposed model has the potential to allow open pit planners to define the confidence level for respecting the stochastic constraints, thus meeting the production targets with a high level of confidence (around 90\%).

\section{References}

Asad, M. W. A. (2010). Implementing a blending optimization model for short-range production planning of cement quarry operation. Journal of mining science, 46(5), 525-535.

Chanda, E. K., and Ricciardone, J. (2002). Long term production scheduling optimisation for a surface mining operation: an application of minemax ${ }^{\mathrm{TM}}$ scheduling software. International Journal of Surface Mining, Reclamation and Environment, 16(2), 144-158.

Charnes A. and Cooper, W.W. (1959). Chance-constrained programming. Management Science, Vol. 6, 73-79.

Charnes A. and Cooper, W.W. (1963). Deterministic equivalents for optimizing and satisficing under chance-constraints. Operation Research, Vol. 11,18-39.

Charnes, A. Cooper, W.W. and Symonds, G. H. (1958). Cost horizons and certainty equivalents: an approach to stochastic programming of heating oil. Management science, 4(3), 235-263.

Chiles, J.P. and Delfiner, P., Geostatistics Modeling Spatial Uncertainty, $2^{\text {th }}$ ed., ISBN: 978-0-470-18315-1, WILEY, Hoboken, NJ, 2012

Dimitrakopoulos, R. and Ramazan, S. (2004). Uncertainty based production scheduling in open pit mining. SME transactions, 316.

Eivazy, H. and Askari-Nasab, H. (2012). A mixed integer linear programming model for short-term open pit mine production scheduling. Mining Technology, 121(2), 97-108. 
Gholamnejad, J., Osanloo, M., and Karimi B. (2006) A chanceconstrained programming approach for open pit long-term production scheduling in stochastic environments, The Journal of the South African Institute of Mining and Metallurgy, 106, 105-114.

Gholamenjad, J. and Osanloo, M. (2007) Using chance constrained binary integer programming in optimising long term production scheduling for open pit mine design, Transactions of the Institutions of Mining and Metallurgy, Section A: Mining Technology, 116, 2, 58-66.

Gholamnejad, J., Osanloo, M., and Khorram, E., (2008) A Chance-constrained integer programming model for open pit long-term production planning, International Journal of Engineering, Transactions A: Basics, 21, 4, 407-418.

Goovaerts, P. (1997). Geostatistics for natural resources evaluation. Oxford University Press on Demand.

Jupp, K., Howard, T.J., and Everett, J.E. (2013). Role of precrusher stockpiling for grade control in iron ore mining. Applied Earth Science, 122(4), 242-255.

Kall, P. and Wallace, S.W. (1994). Stochastic Programming, First Edition, John Wiley and Sons, 305 p.

Kasmaee, S., Tinti, F., and Bruno, R. (2018) Characterization of metal grades in a stockpile of an Iron mine (case study - Choghart iron mine, Iran). Min Geol Petrol Eng Bull 33, 2, 51-60.
Lerchs, H. and Grossman, F.I. (1964) Optimum design of open-pit mines, in Operations Research, Vol.12, B59

Morley, C., and Arvidson, H. (2017). Mine value chain reconciliation-demonstrating value through best practice. In Proceedings of the Tenth International Mining Geology Conference (pp. 279-292).

Newman, A.M., Rubio, E., Caro, R., Weintraub, A. and Eurek, K. (2010). A review of operations research in mine planning. Interfaces, 40(3), 222-245.

Osanloo, M., Gholamnejad, J. and Karimi, B. (2008). Longterm open pit mine production planning: a review of models and algorithms. International Journal of Mining, Reclamation and Environment, 22, 1, 3-35.

Shapiro, A. and Philpott, A. (2007). A tutorial on stochastic programming. Manuscript. Available at www2. isye. gatech. edu/ashapiro/publications. html, 17.

Smith, M. L. (1999). Optimizing inventory stockpiles and mine production: an application of separable and goal programming to phosphate mining using AMPL/CPLEX. CIM bulletin, 92(1030), 61-64.

Yarmuch, J. and Ortiz, J. (2011). A novel approach to estimate the gap between the middle and short-term plans. In Proc. 35th Appl. Comput. Oper. Res. Mineral Indust. (APCOM) Symposium, 419-425.

\section{SAŽETAK}

\section{Primjena stohastičkoga modela na odlagalištu jalovine kao potpora dugoročnoj proizvodnji u otvorenome kopu s ciljem povećanja postotka rude u obradbi}

Rad prikazuje uporabu vjerojatnosnoga cjelobrojnog programiranja, temeljenoga na linearnome algoritmu, za dugoročno rješavanje proizvodnje u rudniku otvorenoga kopa. Obrađeno je jedno odlagalište jalovine sa „siromašnom” koncentracijom rude u cilju aktiviranja toga materijala u budućoj preradbi korisne sirovine. Takav projekt maksimizira trenutačnu vrijednost rudarenja uzimajući u obzir niz fizičkih i ekonomskih varijabli. Posebnost u odnosu na determinističke modele koji se danas uglavnom koriste za izračun granične prosječne vrijednosti koncentracije rude prije odlaganja kao jalovine izražena je stohastikom. Ona je uključila vjerojatnosnu analizu dvaju slučajeva, tj. za ležište željeza i zlata. U obama je dokazano kako se varijable određene na odlagalištu mogu opisati normalnom razdiobom. Stohastički model programiran je za rudnik zlata te je uzeta u obzir optimalna vrijednost rude razvrstane na različitim rudničkim razinama, a prije slanja na obradbu (mljevenje). Optimizirani model zatim je primijenjen za dobivanje usporednoga determinističkog modela. Rezultati su upozorili na to da je konačno rješenje pokazalo znatno bolji odabir granične koncentracije rude koja se mogla poslati na daljnju obradbu. Time je uvećana i ukupna vrijednost rudnika/ležišta.

\section{Ključne riječi:}

dugoročna proizvodnja na otvorenome rudničkom kopu, upravljanje odlagalištem, linearno programiranje, upravljanje rudnikom, stohastički model

\section{Author's contribution}

Prof. Javad Gholamnejad (1) performed the design, implementation of the research and analysis of the results. Eng. Ali Azimi (2) and Eng. Reza Lotfian (3) contributed to the practical application of deterministic and stochastic functions for open pit planning presented in Section 2.2 to the case study of gold mine of Section 3.1. Eng. Ph.D Sara Kasmaeeyazdi (4) investigated the stochastic behaviour of stockpiles presented in Section 2.1. Eng. Ph.D Francesco Tinti (5) contributed to the analyses of Sections 2.1 and 3.1 and to the writing and editing of the manuscript. All authors contributed to the paper's revision. 